\title{
Gambaran Pengetahuan dan Sikap Mahasiswa Fakultas Kedokteran Universitas Andalas tentang Rokok
}

\author{
Yosantaraputra $^{1}$, Yanwirasti $^{2}$, Abdiana $^{3}$
}

\begin{abstract}
Abstrak
Rokok merupakan penyebab kematian sepuluh besar di dunia dimana jumlah kematian mencapai 500 juta orang per tahun. Dalam setiap enam detik terdapat satu kematian akibat rokok.Rokok mengandung lebih dari 4000 senyawa kimia, dimana 60 diantaranya bersifat karsinogenik. Lebih dari 85\% penderita kanker paru adalah perokok. Terdapat juga beberapa kanker lain yang ada hubungannya dengan rokok. Salah satu penyakit yang dapat timbul akibat asap rokok adalah leukemia. Disamping itu rokok dapat meningkatkan resiko penyakit kardiovaskuler.Tujuan penelitian ini adalah untuk mengetahui pengetahuan dan sikap mahasiswa Fakultas Kedokteran Universitas Andalas tentang Rokok. Penelitian ini dilakukan dengan metode penelitian deskriptif dan pengambilan sampel dengan menggunakan teknik Simple Random Sampling dengan jumlah sampel sebanyak 273 orang. Dari hasil penelitian, menunjukkan bahwa tingkat pengetahuan responden terhadap rokok berada dalam kategori baik sebesar $0,4 \%$, kategori sedang sebesar $64,5 \%$, dan kategori kurang sebesar 35,1\%. Hasil uji sikap responden terhadap rokok berada dalam kategori baik sebesar $90,1 \%$, kategori sedang sebesar 9,5\% dan kategori kurang sebesar $0,4 \%$. Dari hasil penelitian ini dapat disimpulkan bahwa pengetahuan mahasiswa Fakultas Kedokteran Universitas Andalas berada pada kategori sedang dan sikap mahasiswa Fakultas Kedokteran Universitas Andalas berada pada kategori baik. Disarankan kepada mahasiswa Fakultas Kedokteran Universitas Andalas agar mencari tahu tentang nikotin dan akibatnya secara mandiri sesuai dengan sistem pembelajaran PBL, serta segera diberlakukannya peraturan bebas asap rokok di lingkungan FK Unand.
\end{abstract}

Kata kunci: pengetahuan, sikap, mahasiswa, rokok.

\begin{abstract}
Cigarettes are the top ten causes of death in the world where each year the total of mortality rate reached 500 million people. In every six seconds there will be found a death caused by smoking. Cigarette contains more than 4000 chemical compounds, in which 60 of the mare carcinogenic. More than $85 \%$ of lung cancer patients are smokers. There are also some other cancers that has relationships withcigarettes. One of the diseases that mayariseas a result of cigarette smokers leukemia. Besides that, smoking may increase the risk of cardiovascular disease. The purpose of this study was to determine the knowledge and attitude of students of the Faculty of Medicine, University of Andalas about Cigarettes. This is a descriptive research method and the sample with drawal is done by using Simple Random Sampling technique witha sample size of 273 people. The results of the study show that respondent's knowledge towards Cigarette is the good category 0,4\%, the average category $64,5 \%$, and the less category $35,1 \%$. The experiment's result on respondent's attitude to wards Cigarette is the good category 90,1\%, the average category $9,5 \%$ and the less category 0,4\%. From these resultsit can be concluded that the knowledge of students of the Faculty of Medicine, University of Andalas in average category and attitude of students of the Facultyof Medicine, University of Andalas are ingood category. It is recommended to students of the Faculty of Medicine, University of Andalas in order tofind out about nicotine and consequently independently in accordance with the PBL learning systems, as well as the enactment ofsmoke-fre elegislation in the Faculty of Medicine, University ofAndalas.
\end{abstract}

Keywords: knowledge, attitude, students, cigarettes 
Affiliasi penulis:1. Fakultas Kedokteran Universitas Andalas, 2. Bagian Patologi Anatomi FK Unand, 3. Bagian Kesehatan Masyarakat FK Unand.

Korespondensi :Yosantaraputra, email : greatdoctor06@gmail.com, Telp : 081272450092

\section{PENDAHULUAN}

Rokok masih menjadi masalah dalam kesehatan karena merupakan satu dari sepuluh kematian di dunia, dimana terdapat 500 juta orang meninggal per tahun akibat merokok. Dalam setiap enam detik terdapat satu kematian akibat rokok. ${ }^{1}$ Sekitar 1,3 milyar perokok di seluruh dunia, $84 \%$ diantaranya di negara-negara berkembang. Sedangkan di negara maju yang terjadi justru sebaliknya, persentase perokok terus menerus cenderung menurun dan saat ini kira-kira hanya 30\% laki-laki dewasa di negara maju yang mempunyai kebiasaan merokok. Hal ini disebabkan tingkat kesadaran masyarakat di negara maju akan bahaya merokok sudah tinggi. Penduduk Indonesia usia dewasa yang mempunyai kebiasaan merokok sebanyak $31,6 \%{ }^{2}$ Dengan besarnya jumlah dan tingginya persentase penduduk yang mempunyai kebiasaan merokok, Indonesia merupakan konsumen rokok tertinggi kelima di dunia dengan jumlah rokok yang dikonsumsi pada tahun 2002 sebanyak 182 milyar batang rokok setiap tahunnya setelah Republik Rakyat China (1.697.291 milyar), Amerika Serikat (463,504 milyar), Rusia (375.000 milyar) dan Jepang (299.085 milyar). ${ }^{3}$

Jumlah prevalensi anak dan remaja yang merokok terus meningkat. Pada tahun 2001 dan 2004 menunjukkan terjadi peningkatan prevalensi merokok pada anak-anak usia 15-19 tahun. Pada tahun 2001 prevalensi merokok pada anak-anak sebesar 12,7\% dan mengalami peningkatan pada tahun 2004 menjadi $17,3 \%{ }^{4}$

Separuh dari 80 ribu sampai 100 ribu anakanak sedunia yang merokok setiap hari berasal dari benua Asia. Pada surveyyang dilakukan di Jakarta, Bekasi, dan Medan pada tahun 2006, didapatkan bahwa prevalensi merokok di Jakarta sebanyak 34\% murid sekolah usia SMP yang pernah merokok dan $16,6 \%$ diantaranya masih merokok, di Bekasi didapatkan 33\% murid sekolah usia SMP pernah merokok dan $17,1 \%$ diantaranya masih merokok, dan di Medan didapatkan 34,9\% murid sekolah usia SMP pernah merokok dan $20,9 \%$ diantaranya masih merokok.

Tingginya persentase penduduk Indonesia yang mempunyai kebiasaan merokok, kesehatan menjadi salah satu faktor yang tidak bisa dikesampingkan. Tercatat tidak kurang dari 4.000 jenis zat kimia yang terkandung dalam sebatang rokok dan 60 zat diantaranya bersifat karsinogenik dan bersifat adiktif. ${ }^{5}$ Jika dilihat dari sisi kesehatan, bahan-bahan kimia yang terkandung di dalam rokok akan memacu kerja dari susunan saraf pusat dan susunan saraf simpatis sehingga dapat mengakibatkan tekanan darah meningkat dan detak jantung bertambah cepat.

Merokok merupakan salah satu penyebab terjadinya $90 \%$ kanker paru pada laki-laki dan 70\% pada perempuan, $22 \%$ dari penyakit jantung dan pembuluh darah, bahkan kematian. Efek rokok membuat penghisap asap rokok mengalami risiko yang lebih tinggi untuk menderita kanker paru-paru, kanker mulut dan tenggorokan, kanker esofagus, kanker kandung kemih, serangan jantung dan berbagai penyakit lain seperti penyempitan pembuluh darah, tekanan darah tinggi, jantung, paru-paru dan bronkitis kronis. ${ }^{6}$ Efek dari rokok tidak hanya dirasakan pada perokok aktif, tetapi juga dapat dirasakan oleh perokok pasif. Risiko yang ditanggung perokok pasif lebih berbahaya dibanding dengan perokok aktif karena daya tahan tubuh terhadap zat-zat yang berbahaya dari rokok lebih rendah Bagi ibu hamil, rokok dapat menyebabkan meningkatnya angka kejadian kelahiran bayi prematur, berat bayi lahir rendah (BBLR), mortalitas prenatal, kemungkinan lahir dalam keadaan cacat dan mengalami gangguan dalam perkembangan.

Pengetahuan merupakan hasil dari tahu, dan ini terjadi setelah orang melakukan pengindraan terhadap suatu objek tertentu. Pengindraan terjadi melalui pancaindra manusia, yakni indra penglihatan, pendengaran, penciuman, rasa dan raba. Sebagian besar pengetahuan manusia diperoleh melalui mata dan telinga. Pengetahuan yang tercakup dalam domain kognitif mempunyai 6 tingkatan, yaitu: tahu (know), memahami (comprehension), aplikasi (application), analisis (analysis), sintesis (synthesis), 
dan evaluasi (evaluation). ${ }^{7}$

Sikap merupakan reaksi atau respon yang masih tertutup dari seseorang terhadap suatu stimulus atau objek. Dari batasan-batasan di atas dapat dapat disimpulkan bahwa manifestasi sikap itu tidak dapat langsung dilihat, tetapi hanya dapat ditafsirkan terlebih dahulu dari perilaku yang tertutup.Sikap secara nyata menunjukkan konotasi adanya kesesuaian reaksi terhadap stimulus tertentu dalam kehidupan seharihari merupakan reaksi yang bersifat emosional terhadap stimulus sosial.Komponen-komponen sikap adalah kognitif, afektif, dan konatif. Seperti halnya dengan pengetahuan, sikap terdiri dari berbagai tingkatan, yaitu: menerima (receiving), merespon (responding), menghargai (valuting), dan bertanggung jawab (responsible).

Perubahan perilaku subjek terhadap rokok dimulai dari subjek mengenal dan mengetahui rokok terlebih dahulu (awareness), selanjutnya subjek mulai tertarik terhadap rokok (interest), setelah itu subjek mulai menimbang-nimbang keuntungan dan kerugian dari rokok terhadap dirinya (evaluation), kemudian subjek mulai mencoba berperilaku merokok (trial) dan akhirnya subjek telah berperilaku baru berupa merokok yang telah disesuaikan dengan pengetahuan, kesadaran dan sikapnya terhadap rokok (adoption). ${ }^{8}$

Perilaku merokok pada remaja merupakan perilaku simbolisasi bagi kaum remaja, dimana merupakan simbol untuk menunjukkan kematangan, kekuatan, kepemimpinan, dan daya tarik terhadap lawan jenis. Selain itu, perilaku merokok juga bertujuan untuk mencari kenyamanan (perasaan nyaman) karena dengan merokok dapat mengurangi ketegangan dan memudahkan berkonsentrasi. Salah satu temuan tentang remaja perokok adalah bahwa anak-anak muda yang berasal dari rumah tangga yang tidak bahagia, dimana orang tua tidak begitu memperhatikan anak-anaknya dan memberikan hukuman fisik yang keras lebih mudah untuk menjadi perokok dibanding anak-anak muda yang berasal dari lingkungan rumah tangga yang bahagia.

Apabila seorang remaja merokok maka semakin besar kemungkinan teman-temannya adalah perokok. Dari fakta tersebut dapat ditarik dua kemungkinan yang terjadi, yaitu remaja tersebut terpengaruh oleh teman-temannya atau teman-teman remaja tersebut dipengaruhi oleh diri remaja tersebut yang akhirnya mereka semua menjadi perokok. Diantara remaja perokok terdapat $87 \%$ mempunyai sekurang-kurangnya satu atau lebih sahabat yang perokok begitu pula dengan remaja non perokok.

Juga didapati bahwa penyebab tersering dari seorang mahasiswa untuk menjadi perokok adalah terpengaruh dari teman-teman sekelompok. ${ }^{9}$ Sebanyak 70,5\% diantaranya yang merokok adalah laki-laki. Dari hasil penelitian tersebut juga didapati bahwa tingkat pengetahuan mahasiswa akan bahaya efek rokok terhadap kesehatan cukup tinggi sedangkan sebanyak $88,5 \%$ sikap mahasiswa merasa tidak nyaman akan keberadaan perokok disekitar mereka tetapi hanya $34,6 \%$ dari mahasiswa yang menegur bila melihat orang merokok. ${ }^{10}$

Tahun 2006 Indonesia melakukan survei dengan menggunakan mahasiswa kedokteran tingkat ketiga sebagai responden dalam survei. Mahasiswa kedokteran diharapkan akan berperan penting untuk menurunkan kebiasaan merokok, sekaligus memberikan informasi dampak merokok terhadap kesehatan, termasuk membantu berhenti merokok dan memberi contoh gaya hidup bebas rokok. Hampir setengah $(48,4 \%)$ dari mahasiswa kedokteran pernah merokok. Prevalensi merokok mahasiswa kedokteran adalah laki-laki $21,1 \%$ dan perempuan $2,3 \%$. Sepertiganya (33\%) sudah merasa ingin merokok kurang dari 30 menit setelah bangun tidur di pagi hari, pada perempuan $39,4 \%$, lebih tinggi dari laki-laki sebesar $31,9 \%$. Ini menunjukkan tingkat kecanduan merokok yang tinggi. ${ }^{11}$

\section{METODE}

Rancangan penelitian yang digunakan adalah penelitian deskriptif. Penelitian deskriptif ini dilakukan terhadap sekumpulan objek biasanya cukup banyak, dalam jangka waktu tertentu yang bertujuan untuk mengetahui gambaran pengetahuan dan sikap mahasiswa Fakultas Kedokteran Universitas Andalas terhadap rokok. Pengambilan data dilakukan hanya sekali saja pada setiap responden.

\section{Populasi dan Sampel}

Populasi dalam penelitiaan ini adalah mahasiswa Fakultas Kedokteran Universitas Andalas angkatan 
2010, angkatan 2011, dan angkatan 2012.Populasi pada penelitian ini berumlah sekitar 850 orang. Jumlah sampel adalah sebanyak 272 orang.

\section{Teknik Pengambilan Sampel}

Teknik pengambilan sampel dengan menggunakan teknik stratified random sampling.

\section{Pemilihan sampel}

Karena jumlah mahasiswa pada setiap tingkat kurang lebih sama, maka diambil sampel pada setiap tingkat secara simple random sampling (diambil dari setiap nomor absen ganjil).

\section{Pengukuran Variabel}

Pengukuran gambaran pengetahuan mahasiswa FK UNAND mengenai rokok dilakukan berdasarkan jawaban pertanyaan yang diberikan oleh responden. Instrumen yang digunakan berupa angket dengan jumlah pertanyaan sebanyak 25 pertanyaan. Bila jawaban responden benar akan diberi nilai 1 , jika jawaban salah diberi nilai 0 . Pengukuran sikap mahasiswa FK UNAND mengenai rokok dilakukan berdasarkan jawaban pertanyaan yang diberikan oleh responden.Instrumen yang digunakan berupa angket dengan jumlah pertanyaan sebanyak 10 pertanyaan. Bila jawaban responden setuju maka akan diberi nilai 1, jika jawaban tidak setuju diberi nilai 0 .

\section{Pengolahan data}

Data dari setiap responden akan dimasukkan ke dalam komputer oleh peneliti. Analisis data yang diperoleh dilakukan secara deskriptif dengan menggunakan komputer.

HASIL

Responden yang menjadi sampel dalam penelitian ini adalah mahasiswa Fakultas Kedokteran Universitas Andalas angkatan 2010, 2011, dan 2012, dengan jumlah responden sebanyak 273 orang.

Dari keseluruhan responden yang ada diperoleh gambaran mengenai karakteristiknya meliputi: jenis kelamin, aktivitas responden selain kuliah, usia pertama kali mengenal rokok, dan riwayat merokok. Data lengkap mengenai karakteristik responden tersebut dapat dilihat pada tabel 1, tabel 2, tabel 3, tabel 4, tabel 5 dan tabel 6 .

Pada penelitian ini jumlah jenis kelamin lakilaki dan perempuan tidak dibatasi, karena dalam penelitian ini peneliti hanya ingin melihat gambaran pengetahuan dan sikap dari responden tentang rokok, peneliti tidak membandingkan pengetahuan dan sikap tentang rokok berdasarkan jenis kelamin.

Dari tabel 1.dapat dilihat bahwa responden terbanyak yaitu responden dengan jenis kelamin perempuan $64,5 \%$ dan responden laki-laki 35,5\%. Dari tabel 2 dapat dilihat bahwa kegiatan responden selain kuliah yaitu responden mengikuti organisasi $61,5 \%$, olahraga $17,6 \%$, berdagang $1,5 \%$ dan sebanyak $19,4 \%$ responden memiliki kegiatan lain selain berorganisasi, berolahraga dan berdagang. Dari tabel 3. dapat dilihat bahwa responden mengenal rokok berdasarkan jenjang pendidikan dapat sangat bervariasi, yaitu sejak TK 47,3\%, SD 47,6\%, SMP 4,3\% dan SMA 0,7\%. Dari hasil tersebut persentase terbesar responden mengenal rokok adalah pada saat pendidikan SD dan persentase terkecil adalah pada saat pendidikan SMA. Dari tabel 4. dapat dilihat bahwa riwayat merokok responden cukup bagus yaitu responden yang merokok hanya 3,7\% dan yang tidak merokok 96,3\%. Dari tabel 5 dapat dilihat bahwa tingkat pengetahuan yang dikategorikan baik sebesar $0,4 \%$, tingkat pengetahuan yang dikategorikan sedang sebanyak $64,5 \%$ dan tingkat pengetahuan dengan kategori kurang memiliki persentase 35,1\%.Dari tabel 6.dapat dilihat bahwa sikap yang dikategorikan baik memiliki persentase yang besar yaitu $90,1 \%$, sedangkan sikap dengan kategori sedang sebesar $9,5 \%$ dan sikap dengan kategori kurang hanya $0,4 \%$.

\section{PEMBAHASAN}

Dari keseluruhan responden yang ada, diperoleh gambaran mengenai karakteristiknya meliputi: jenis kelamin, aktivitas responden selain kuliah, usia pertama kali mengenal rokok, dan riwayat merokok. Responden terbanyak yaitu responden dengan jenis kelamin perempuan $64,5 \%$ sedangkan responden laki-laki 35,5\%. Dari hasil penelitian didapatkan kegiatan responden selain kuliah yaitu: responden mengikuti organisasi $61,5 \%$, olahraga $17,6 \%$, berdagang $1,5 \%$ dan sebanyak $19,4 \%$ 
responden memiliki kegiatan lain selain berorganisasi, berolahraga dan berdagang. Dari hasil penelitian didapatkan responden mengenal rokok berdasarkan jenjang pendidikan sangat bervariasi, yaitu: sejak TK $47,3 \%$, SD 47,6\%, SMP 4,3\% dan SMA 0,7\%. Dari hasil tersebut persentase terbesar responden mengenal rokok adalah pada saat pendidikan SD dan persentase terkecil adalah pada saat pendidikan SMA. Dari hasil penelitian juga didapatkan riwayat merokok responden cukup bagus yaitu responden yang merokok hanya 3,7\% dan yang tidak merokok $96,3 \%$.

Secara keseluruhan diperoleh sebanyak 1 responden $(0,4 \%)$ yang berpengetahuan baik, 176 responden $(64,5 \%)$ yang berpengetahuan sedang, dan 96 responden $(35,1 \%)$ yang berpengetahuan kurang.

Berdasarkan hasil tersebut terlihat bahwa sebagian besar pengetahuan tentang rokok pada mahasiswa angkatan 2010, angkatan 2011, dan angkatan 2012 Fakultas Kedokteran Unand berada pada tingkat sedang. Hasil dari penelitian ini sama dengan yang pernah diteliti oleh Jeff Loren dari Fakultas Kedokteran Universitas Sumatera Utara pada tahun 2009 dan Nisrina Hanisa dari Fakultas Keperawatan Universitas Padjajaran 2008 dengan hasil tingkat pengetahuan sedang dan sikap baik. Menurut peneliti, hal ini mungkin karena mahasiswa kurang aktif mencari informasi. Informasi akan memberikan pengaruh pada pengetahuan seseorang. ${ }^{8}$

Berdasarkan hasil analisa secara keseluruhan dapat dilihat bahwa sikap mahasiswa FK Unand terhadap rokok berada pada kategori baik $(90,1 \%)$. Hasil dari penelitian ini sama dengan yang pernah diteliti oleh Jeff Loren dari Fakultas Kedokteran Universitas Sumatera Utara pada tahun 2009 dan Nisrina Hanisa dari Fakultas Keperawatan Universitas Padjajaran 2008 dengan hasil tingkat pengetahuan sedang dan sikap baik. Bila dilihat dari pengetahuan responden yang sedang, maka hal ini bertolak belakang dengan teori ada. Pengetahuan yang diperoleh subjek selanjutnya akan menimbulkan respon batin dalam bentuk sikap terhadap objek yang telah diketahuinya, sehingga dapat disimpulkan bahwa bila pengetahuan yang baik akan memiliki sikap yang baik juga. ${ }^{2}$ Tetapi dalam penelitian ini didapati hasil pengetahuan dan sikap tidak sejalan, dimana pengetahuan yang diperoleh dalam penelitian ini berada pada kategori sedang $(64,5 \%)$ sedangkan sikap dalam penelitian ini berada pada kategori baik $(90,1 \%)$.

Hal ini mungkin disebabkan oleh berbagai faktor yang dapat mempengaruhi sikap responden sehingga memiliki sikap yang baik walaupun dengan pengetahuan yang sedang. Sikap dapat dipengaruhi oleh faktor-faktor lain seperti lingkungan, kebudayaan, adat istiadat, ataupun pengalaman, sehingga walaupun dengan pengetahuan yang sedang tetapi responden dapat memiliki sikap yang baik. ${ }^{2}$

\section{KESIMPULAN}

Berdasarkan uraian-uraian yang telah dipaparkan, maka dalam penelitian ini dapat disimpulkan, yaitu, sebagian besar pengetahuan mahasiswa Fakultas Kedokteran Universitas Andalas tentang Rokok berada pada kategori sedang dan hampir seluruh mahasiswa Fakultas Kedokteran Universitas Andalas mempunyai sikap yang baik tentang rokok.

\section{TABEL}

Tabel 1. Distribusi Karakteristik Responden berdasarkan Jenis Kelamin

\begin{tabular}{ccc}
\hline Jenis Kelamin & $\mathbf{f}$ & $\%$ \\
\hline Laki-laki & 97 & 35,5 \\
Perempuan & 176 & 64,5 \\
Jumlah & 273 & 100 \\
\hline
\end{tabular}

Keterangan:

$f$ : frekuensi

Tabel 2. Distribusi Karakteristik Responden berdasarkan Aktivitas Responden selain Kuliah

\begin{tabular}{ccc}
\hline Aktivitas & $\mathbf{f}$ & $\%$ \\
\hline Organisasi & 168 & 61,5 \\
Olahraga & 48 & 17,6 \\
Berdagang & 4 & 1,5 \\
Lain-lain & 53 & 19,4 \\
Jumlah & 273 & 100 \\
\hline
\end{tabular}

Keterangan :

$f$ : frekuensi 
Tabel 3. Distribusi Karakteristik Responden Mengenal Rokok berdasarkan Jenjang Pendidikan

\begin{tabular}{ccc}
\hline $\begin{array}{c}\text { Jenjang } \\
\text { Pendidikan }\end{array}$ & $\mathbf{f}$ (frekuensi) & $\%$ \\
\hline TK & 129 & 47,3 \\
SD & 130 & 47,6 \\
SMP & 12 & 4,3 \\
SMA & 2 & 0,7 \\
Jumlah & 273 & 100 \\
\hline
\end{tabular}

Keterangan :

$f$ : frekuensi

Tabel 4. Distribusi Karakteristik Responden berdasarkan Riwayat Merokok

\begin{tabular}{ccc}
\hline $\begin{array}{c}\text { Riwayat } \\
\text { Merokok }\end{array}$ & f (frekuensi) & $\%$ \\
\hline Merokok & 10 & \\
Tidak Merokok & 263 & 96,3 \\
Jumlah & 273 & 100 \\
\hline Keterangan: & & \\
$\mathbf{f}:$ frekuensi & &
\end{tabular}

Tabel 5. Distribusi Frekuensi Responden berdasarkan Pengetahuan

\begin{tabular}{ccc}
\hline Pengetahuan & F & $\%$ \\
\hline Kurang & 96 & 35,1 \\
Sedang & 176 & 64,5 \\
Baik & 1 & 0,4 \\
Total & 273 & 100 \\
\hline
\end{tabular}

Keterangan :

$f$ : frekuensi

Tabel 6. Distribusi Frekuensi Responden berdasarkan Sikap

\begin{tabular}{ccc}
\hline Sikap & $\mathbf{f}$ & $\%$ \\
\hline Kurang & 1 & 0,4 \\
Sedang & 26 & 9,5 \\
Baik & 246 & 90,1 \\
Total & 273 & 100 \\
\hline
\end{tabular}

Keterangan tabel :

f : frekuensi

\section{UCAPAN TERIMAKASIH}

Ucapan terimakasih kepada Prof. Dr. dr. Yanwirasti dan Abdiana, S.KM, M.Epid, yang telah banyak memberikan bimbingan, bantuan dan motivasi dalam penelitian ini.

\section{DAFTAR PUSTAKA}

1. WHO. Who report on the Global Tobacco Epidemic.WHO. Available from: http://www.who.int/tobacco/mpower report fu II 2008.pdf. [Accessed 17 Maret 2013]; 2008.

2. Departemen Kesehatan Republik Indonesia. Murid SMP Terlalu Mudah Membeli Rokok. Direktorat Jendral Kesehatan Masyarakat, Direktorat Promosi Kesehatan; 2009.

3. Departemen Kesehatan Republik Indonesia. Perokok Pasif Mempunyai Risiko Lebih Besar Dibandingkan Perokok Aktif. Direktorat Jendral Kesehatan Masyarakat, Direktorat Promosi Kesehatan; 2004.

4. Perhimpunan Dokter Paru Indonesia.Prevalensi Merokok Pada Anak Terus Meningkat. Indonesia: Perhimpunan Dokter Paru Indonesia. Available from: http://www.kikil.org/forum/printthread.php?tid =7394. [Accessed 12 Maret 2013]; 2003.

5. Gondodiputro S. Bahaya Tembakau dan Bentuk-bentuk Sediaan Tembakau. Bagian IImu Kesehatan Masyarakat Fakultas Kedokteran Universitas Padjajaran. Available from: http://resources.unpad.ac.id/unpadcontent/uploads/publikasi dosen/Rokok.PDF. [Accessed 23 Maret 2013]; 2007.

6. Kaplan RM, Sallis JF, Patterson TL. Health and Human Behavior. New York: McGraw-Hill Book Co; 1993.

7. Notoadmodjo S. Pendidikan dan Perilaku Kesehatan. Dalam: Notoadmodjo S. IImu Kesehatan Masyarakat: Prinsip-prinsip Dasar. Jakarta: Rineka Cipta. 2003; 95-45. 
8. Notoadmodjo S. Metodologi Penelitian Kesehatan. Jakarta: Rineka Cipta; 2005.

9. Whelton PK. Passive Smoking and The Risk of Coronary Heart Disease: A Meta-analysis of epidemiologic study. N Engl J Med. 1999; 340: 920-26.

10. Itil O, Ergor G, Ceylan E. Knowledge and Attitudes About Smoking Among Students In A Medical Faculty. Turkish Respiratory $J 5$. 2005; (2): 86-91.

11. Menteri Perindustrian dan Perdagangan RI. Keputusan Menteri Perindustrian dan Perdagangan Republik Indonesia Tentang Pedoman Cara Uji Kandungan Kadar Nikotin dan Tar Rokok.Direktorat Jendral Industri Kimia, Argo dan Hasil Hutan; 2004.

12. Alsagaff $H$, Mukty HA. Penyakit Obstruksi Saluran Pernafasan. Dalam: Alsagaff $\mathrm{H}$, Mukty HA. Dasar-dasar IImu Penyakit Paru. Surabaya: Airlangga University Press. 2006; 231-53.

13. Amin Z. Kanker Paru. Dalam: Sudoyo AW, Setryohadi B, Alwi I, Simadibrata MK, Setiati S. IImu Penyakit Dalam. Ed 4. Jakarta: Pusat
Penerbitan Departemen IImu Penyakit Dalam Fakultas Kedokteran Universitas Indonesia. 2006; 1015-21.

14. CurfmanGD, Morrissey S, Drazen JM. The FDA and Tobacco Regulation. $N$ Eng $J$ Med. 2008; 359(10): 1056-57.

15. Departemen Kesehatan Republik Indonesia. Kematiaan Akibat Rokok Berlipat Ganda Pada Tahun 2020. Direktorat Jendral Kesehatan Masyarakat, Direktorat Promosi Kesehatan; 2006.

16. Isselbacher B dkk. Harrisons' Principles of Internal Medicine, $10^{\text {th }}$ Ed. New York: McGraw-Hill Company. 1999; 1302-05.

17. Notoadmodjo S. Konsep Perilaku dan Perilaku Kesehatan. Dalam: Notoadmodjo S. Promosi Kesehatan dan IImu Perilaku. Jakarta: Rineka Cipta. 2007; 133-51.

18. Tim Penyusun Kamus Pusat. Kamus Besar Bahasa Indonesia. Jakarta: Balai Pustaka; 2008.

19. World Bank. Tobacco Control in Developing Countries.World Bank. Available from: http://wwwl.worldbank.org/tobacco/tcdc/465T O476.pdf. [Accessed 27 Maret 2013]; 2001. 